\title{
DETERMINASI FAKTOR PENTING BERDASARKAN AKTIVITAS MASYARAKAT UNTUK PENGEMBANGAN KAWASAN REHABILITASI HUTAN MANGROVE DI PANTAI KARANGSONG, KABUPATEN INDRAMAYU
}

\author{
Determination of Important Factorson Society Activity for The Development of The Mangrove Forests \\ Rehabilitation Area on The Beach of Karangsong, District of Indramayu \\ Halimatus Sa'diyah, Boedi Hendrarto dan Siti Rudiyanti \\ Program StudiManajemenSumberdayaPerairan, JurusanPerikanan \\ FakultasPerikanandanIlmuKelautan, UniversitasDiponegoro \\ Jl. Prof. Soedarto, SH, Tembalang, Semarang, Jawa Tengah - 50275, Telp/Fax. +6224 7474698 \\ Email: hlmtssdyh24@yahoo.com
}

Diserahkan tanggal 16 Mei 2017, Diterima tanggal 23 Juni 2017

\begin{abstract}
ABSTRAK
Hutan mangrove di Pantai Karangsong, Kabupaten Indramayu merupakan salah satu hutan mangrove di Pantai Utara Jawa yang telah direhabilitasi. Kawasan rehabilitasi mangrove telah dimanfaatkan oleh masyarakat sebagai lokasi wisata (ekowisata) dan lokasi mata pencaharian. Agar pengembangan selanjutnya dapat berjalan secara tepat, diperlukan perencanaan berdasarkan faktor-faktor penting yang berkaitan dengan pengelolaan hutan tersebut dalam kategori masyarakat yang berbeda, yaitu masyarakat yang berada dalam kawasan hutan mangrove, pengelola kawasan hutan mangrove dan pelaku perikanan. Tujuan dari penelitian ini adalah adalah untuk mengetahui faktor penting untuk pengembangan di kawasan rehabilitasi mangrove berdasarkan aktivitas masyarakat. Penelitian ini dilakukan di kawasan rehabilitasi hutan mangrove Pantai Karangsong, Kabupaten Indramayu pada bulan Agustus - September 2016. Metode yang digunakan adalah studi kasus yang bersifat deskriptif. Variabel penelitian terdiri dari kondisi sosial dan ekonomi masyarakat yaitu pendidikan, umur, pekerjaan dan pendapatan. Pengambilan data dilakukan melalui wawancara menggunakan kuisioner tertutup dan observasi untuk melakukan pengamatan terhadap sumberdaya manusia. Analisis data menggunakan analisis multivariat, yaitu analisis faktor. Hasil penelitian menunjukkan bahwa faktor-faktor penting yang didapatkan untuk kategori masyarakat terdiri dari (1) wisata alam, (2) faktor fungsi dan manfaat, (3) faktor partisipasi masyarakat dalam pengelolaan serta frekuensi pemanfaatan dan faktor (4) pengetahuan. Faktor penting untuk kategori pengelola terdiri dari (1) faktor upaya pengelolaan dan (2) faktor pengaruhnya serta respon masyarakat terhadap pengelolaan. Faktor penting untuk kategori pelaku perikanan terdiri dari (1) faktor pengetahuan, (2) faktor frekuensi pemanfaatan serta fungsi dan (3) faktor perusak ekosistem.
\end{abstract}

Kata kunci: Mangrove, Aktivitas Masyarakat, Faktor Penting, Pengembangan Rehabilitasi, Pantai Karangsong

\section{ABSTRACT}

The mangrove forest of Karangsong, Indramayu Regency is one of the mangrove forests on the northern coast of Java that has been rehabilitated. Mangrove rehabilitation area had been utilized by the public as a tourist site (ecotourism) and location of livelihood. In order for future development can be run properly, required planning based on important factors related to the forest management in different communities, i.e., communities that are in the area of mangrove forests, mangrove forest area manager and performer fisheries. The purpose of this research was to know the important factors for development of mangrove rehabilitation area based on the activity of the society. This research was conducted in the mangrove forests rehabilitation area on the beach of Karangsong, District of Indramayu in August - September 2016.This research was a case study. The variables consisted of research social and economic conditions, namely education, ages, employment and income.. Data were collected through interviews using the enclosed questionnaire and observations. Data analysis using multivariate analysis of factors. The results showed that the important factors obtained for category community consisted of (1) nature tourism factors, (2) the factors of function and benefits, (3) the factors of community participation in management as well as the frequency of utilization and (4) factors of knowledge. An important factor for the category manager consisted of (1) factors and management efforts (2) factors influence as well as the response of the community towards the management. An important factor for the category of perpetrators of fisheries consisted of (1) the factors of knowledge, (2) the frequency utilization factor as well as the functions and (3) factors of damaging the ecosystem.

Keywords: Mangrove, Society Activity, Important Factors, Development of Rehabilitation, Beach of Karangsong 


\section{PENDAHULUAN}

Masyarakat Desa Karangsong memiliki berbagai macam kepentingan untuk memanfaatkan wilayah pesisir, diantaranya sebagai pemukiman, kegiatan perikanan (menangkap ikan), tempat mencari nafkah (berjualan makanan dan lain-lain) dan dijadikan sebagai lokasi wisata alam. Berbagai aktivitas tersebut menyebabkan penurunan luas hutan mangrove dan berakibat juga pada penurunan fungsi dan manfaat mangrove bagi penduduk serta lingkungan sekitarnya.Rendahnya pengetahuan dan informasi masyarakat, pengelola dan pelaku perikanan mengenai faktor penting suatu ekosistem mangrove menjadi kendala dalam mengembangkan kegiatan rehabilitasi mangrove. Hal tersebut membuat pengelola tidak memiliki acuan yang cukup untuk membuat perencanaan atau strategi dalam mengembangkan kawasan rehabilitasi mangrove yang mereka lakukan. Ancaman perusakan lingkungan ekosistem mangrove lebih banyak datang dari kegiatan manusia seperti limbah domestik baik yang dibuang oleh masyarakat maupun oleh pengunjung. Kurangnya campur tangan pemerintah daerah dalam pengelolaan kawasan rehabilitasi mangrove merupakan masalah lainnya yang ada di kawasan rehabitasi mangrove. Savitri dan Khazali (1999) berpendapat bahwa kondisi hutan mangrove di Desa Karangsong yang semakin memprihatinkan tersebut disebabkan oleh dua hal, yakni karena adanya kegiatan pengalih fungsian hutan mangrove dan juga diperparah dengan adanya permasalahan abrasi pantai yang menimpa desa tersebut. Abrasi pantai terjadi beberapa saat setelah adanya pengalihan aliran Sungai Cimanuk ke arah Bangkir pada tahun 1979 agar tidak melewati pusat kota. Hal tersebut menyebabkan terputusnya aliran ke Sungai Prajagumiwang, sehingga pasokan sedimen bagi daerah tersebut juga ikut terhenti. Berdasarkan data dari Dinas Perikanan dan Kelautan, Kabupaten Indramayu termasuk salah satu wilayah yang memiliki tingkat kerusakan hutan mangrove terparah di Jawa Barat. Hutan mangrove yang tergolong rusak berat sekitar $50 \%$ dari 17,782 ha.

Hutan mangrove Karangsong mulai dirawat sejak tahun 2008 dan berbenah menjadi ekowisata melalui program CSR (Corporate Social Responsibility) Pertamina RU VI Balongan yang dimulai dari tahun 2010 hingga 2014 serta dikelola oleh kelompok masyarakat lokal yakni Kelompok Pantai Lestari. Lokasi ini telah dirancang sebagai mangrove center untuk wilayah Barat Indonesia oleh Menteri Lingkungan Hidup dan Kehutanan RI Siti Nurbaya ketika membuka kegiatan Karangsong Mangrove Festival di Pantai Karangsong, Indramayu. Melalui Peraturan Desa Nomor 02 Tahun 2009 tentang Pengelolaan Daerah Perlindungan Mangrove Desa Karangsong, bahwa seluas 15 ha yang dikelola oleh Kelompok Pantai Lestari telah ditetapka sebagai Daerah Perlindungan Mangrove (DPM).

Pemanfaatan kawasan hutan mangrove tersebut semakin berkembang sejak adanya program rehabilitasi. Pemanfaatan sumberdaya yang tidak merusak dan sekaligus dapat menjaga kondisi sumberdaya tersebut adalah pemanfaatan yang berbasis ekowisata.Berdasarkan data dan informasi dari hasil penelitian Prayudha et al. (2014) mengenai strategi pengembangan ekowisata mangrove Desa Karangsong, menyebutkan bahwa salah satu strategi dalam pengembangan mangrove disana mempunyai potensi dan peluang untuk dijadikana sebagai pengembangan kawasan mangrove eduwisata. Konsep pengelolaan ekowisata dapat mengajak masyarakat untuk ikut serta dalam memelihara dan menjaga kelestarian hutan mangrove. Purnamasari et al. (2015) menjelaskan bahwa tingkat persepsi masyarakat dan pengelola masih rendah mengenai pengertian ekowisata dan pengelolaan sumberdaya berbasis ekowisata. Partisipasi dalam pengelolaan ekowisata oleh masyarakat masih belum dilibatkan sepenuhnya dan hanya dilakukan oleh setiap anggota kelompok pengelola.

Aktivitas masyarakat yang terdiri dari faktor lingkungan dan sosial memiliki peranan penting dalam pengelolaan kawasan rehabilitasi hutan mangrove. Hal tersebut dapat menjadi dasar dalam membuat strategi pengembangan yang tepat dan sesuai untuk kawasan rehabilitasi hutan mangrove.

\section{METODE PENELITIAN}

Penelitian merupakan studi kasus yang bersifat deskriptif. Penelitian terhadap faktor penting berdasarkan aktivitas masyarakat, dilakukan dalam beberapa tahapan. Uji pendahuluan dilakukan dengan melakukan wawancara semi terstruktur menggunakan kuisioner tertutup (closed questionaire), yaitu kuisioner yang terdiri dari serangkaian pertanyaan yang sudah disediakan jawabannya sehingga responden tinggal memilih (Arikunto, 2006).Pengujian kuisioner terdiri dari uji reliabilitas dan uji validitas. Apabila indikator (variabel) dalam pertanyaan layak (reliabel dan valid), maka kuisioner dapat digunakan dalam penelitian. Pengumpulan data menggunakan kuisioner yang telah layak. Responden yang dipilih adalah masyarakat yang melakukan kegiatan baik secara langsung maupun tidak langsung di kawasan rehabilitasi mangrove, masyarakat yang sudah lama melakukan kegiatan di kawasan tersebut minimal 4 tahun, dan masyarakat yang dianggap mampu serta mengetahui tentang kawasan rehabilitasi mangrove. Jumlah sampel adalah 32 responden karena penelitiannya korelasional, sehingga sampel minimumnya adalah 30 subjek (Gay dan Diehl, 1992). Responden terbagi menjadi 3 kategori, yaitu 21 masyarakat, 6 pengelola dan 5 pelaku perikanan. Penentuan jumlah sampel kategori pengelola menggunakan teknik sensus, karena jumlah populasinya sedikit (terbatas) sehingga tidak memungkinkan untuk menggunakan sampel dan mengambil jumlah sampel sama dengan jumlah populasi (Sugiyono, 2008). Penentuan jumlah sampel kategori pelaku perikanan menggunakan teknik purposive (Sugiyono, 2012), dimana pengambilan sampel yang memiliki pertimbangkan bahwa responden yang dipilih adalah mereka yang mengerti dan mengetahui kondisi kawasan rehabilitasi mangrove. Penelitian terhadap faktor penting berdasarkan aktivitas masyarakat dilakukan dalam beberapa tahapan, diantaranya melakukan uji pendahuluan. Uji pendahuluan dilakukan dengan melakukan wawancara menggunakan kuisioner dengan maksud untuk mengetahui gambaran tentang kondisi sosial dan ekonomi masyarakat sekitar kawasan rehabilitasi mangrove. Setelah uji pendahuluan dilakukan, langkah selanjutnya adalah melakukan pengujian kuisioner (uji reliabilitas dan uji validitas). Apabila kuisioner dinyatakan memenuhi syarat (reliabel dan valid), selanjutnya kuisioner dapat digunakan dalam penelitian (Ghozali, 2011). Setelah data terkumpul, selanjutnya dilakukan analisis multivariat menggunakan analisis faktor. Dalam analisis ini dicari faktor-faktor yang mampu menjelaskan hubungan atau

${ }^{\circ}$ Copyright by Saintek Perikanan (Indonesian Journal of Fisheries Science and Technology), ISSN : 1858-4748 
korelasi antara berbagai indikator yang independen yang diobservasi. Sebagai hasilnya bisa dibuat satu atau beberapa kumpulan variabel yang lebih sedikit dari jumlah varibel awal (Hair et al., 1998).

\section{HASIL DAN PEMBAHASAN}

\section{a. Masyarakat dalam Kawasan Hutan Mangrove}

Berdasarkan pengamatan dan analisis variabel untuk masyarakat, ternyata didapatkan 15 variabel yang dapat dikategorikan dalam 4 faktor penting. Hasil analisis faktor dapat diliihat pada Tabel 1.

Tabel 1. Matriks Rotasi Komponen Kategori Masyarakat

\begin{tabular}{|c|c|c|c|c|c|}
\hline \multirow[t]{2}{*}{ Kode } & \multicolumn{4}{|c|}{ Faktor } & \multirow[t]{2}{*}{ Keterangan } \\
\hline & 1 & 2 & 3 & 4 & \\
\hline $\mathrm{C} 3.5$ & ,929 & 034 & , 175 & ,036 & $\begin{array}{l}\text { Faktorpenggangguekosi } \\
\text { stem }\end{array}$ \\
\hline E7 & 843 &, 044 & , 184 & ,279 & $\begin{array}{l}\text { Kegiatan ekonomi di } \\
\text { area wisata }\end{array}$ \\
\hline E5 &, 821 &, 332 & 060 & ,141 & $\begin{array}{l}\text { Potensi untuk tempat } \\
\text { wisata }\end{array}$ \\
\hline E6 & ,711 &, 314 &, 454 &, 110 & Jenis wisata \\
\hline $\mathrm{C} 2.5$ & 660 & ,394 & ,366 &,- 109 & $\begin{array}{l}\text { Fungsi sosial hutan } \\
\text { mangrove }\end{array}$ \\
\hline E4 & 599, & ,083 &,- 118 & ,336 & $\begin{array}{l}\text { Asal } \\
\text { pengunjung/wisatawan }\end{array}$ \\
\hline $\mathrm{C} 2.4$ & , 195 &, 889 & ,236 & ,009 & $\begin{array}{l}\text { Fungsi fisik hutan } \\
\text { mangrove }\end{array}$ \\
\hline $\mathrm{C} 2.3$ & ,287 &, 876 & , 149 &,- 064 & $\begin{array}{l}\text { Fungsi ekonomi hutan } \\
\text { mangrove }\end{array}$ \\
\hline $\mathrm{C} 2.2$ & ,078 &, 767 &,- 264 &, 161 & $\begin{array}{l}\text { Fungsi ekologis hutan } \\
\text { mangrove }\end{array}$ \\
\hline $\mathrm{C} 3.2$ & 049 & ,726 &, 524 & ,102 & $\begin{array}{l}\text { Manfaat hutan bagi } \\
\text { manusia }\end{array}$ \\
\hline $\mathrm{C} 2.1$ & , 118 & ,708 & ,260 & ,414 & $\begin{array}{l}\text { Pengetahuan fungsi } \\
\text { hutan mangrove }\end{array}$ \\
\hline D2 & , 100 &, 031 & ,911 &, 120 & $\begin{array}{l}\text { Keikutsertaan dalam } \\
\text { pengelolaan }\end{array}$ \\
\hline E8 & ,299 & ,222 &, 839 & ,072 & $\begin{array}{l}\text { Efek negatif hutan } \\
\text { mangrove menjadi area } \\
\text { wisata }\end{array}$ \\
\hline $\mathrm{C} 3.3$ & ,219 &, 073 & , 162 & ,902 & $\begin{array}{l}\text { Frekuensi pemanfaatan } \\
\text { hutan mangrove }\end{array}$ \\
\hline E2 & ,362 & ,484 &, 050 & ,512 & $\begin{array}{l}\text { Pengetahuan tentang } \\
\text { ekowisata }\end{array}$ \\
\hline
\end{tabular}

Sumber: Hasil Penelitian, 2016

Tabel 1 menunjukkan bahwa terdapat 4 faktor penting dalam kategori masyarakat dimana faktor 1 yang memiliki nilai korelasi 0,929 sampai 0,599 ; faktor 2 yang memiliki nilai korelasi 0,889 sampai 0,708 ; faktor 3 yang memiliki nilai korelasi 0,911 sampai 0,839 ; dan faktor 4 yang memiliki nilai korelasi 0,902 sampai 0,512 . Adapun faktor-faktor tersebut dapat dilihat pada Gambar 1.

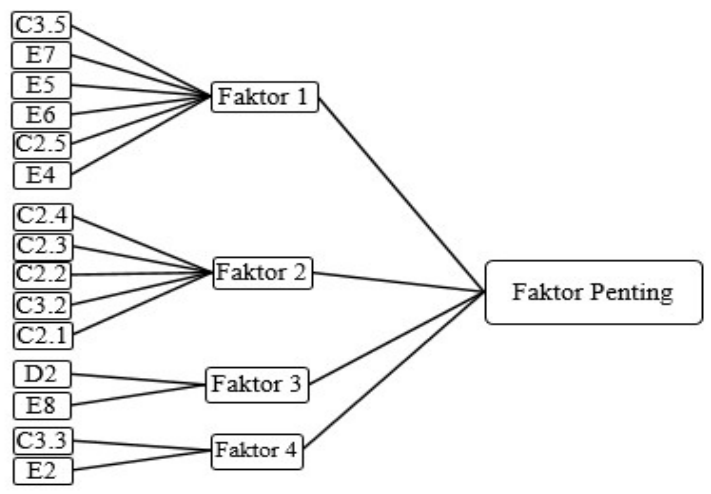

Gambar 1. Faktor Penting Masyarakat

Faktor 1 disebut sebagai faktor wisata alam. Faktor 2 merupakan faktor fungsi dan manfaat hutan mangrove. Faktor 3 merupakan faktor partisipasi masyarakat dalam pengelolaan. Faktor 4 merupakan faktor frekuensi pemanfaatan dan pengetahuan. Nilai yang didapat pada masing-masing variabel dalam faktor 1 , faktor 2 , faktor 3 dan faktor 4 adalah positif, yang artinya apabila salah satu nilai variabel naik maka nilai variabel lainnya naik. Misalnya hubungan antara variabel C3.5 dan E7 pada faktor 1, dimana faktor pengganggu ekosistem (C3.5) tinggi apabila kegiatan ekonomi di area wisata (E7) tinggi. Sebaliknya, faktor pengganggu ekosistem (C3.5) rendah apabila kegiatan ekonomi di area wisata (E7) rendah. Hal ini berlaku pada hubungan antara variabel $\mathrm{C} 3.5$ dan $\mathrm{E} 5$; C3.5 dan E6; C3.5 dan C2.5; C3.5 dan E4; E7 dan E5; E7 dan E6; E7 dan $\mathrm{C} 2.5$; E7 dan E4; E5 dan E6; E5 dan C2.5; E5 dan E4; serta $\mathrm{C} 2.5$ dan $\mathrm{E} 4$.

Hubungan antara variabel C3.2 dan C2.1 pada faktor 2, dimana manfaat hutan bagi manusia (C3.2) tinggi dikarenakan pengetahuan masyarakat tentang fungsi hutan mangrove tinggi (C2.1). Sebaliknya, manfaat hutan bagi manusia (C3.2) rendah dikarenakan pengetahuan masyarakat tentang fungsi hutan mangrove $(\mathrm{C} 2.1)$ rendah. Hal ini berlaku pada hubungan antara variabel $\mathrm{C} 2.4$ dan $\mathrm{C} 2.3$; $\mathrm{C} 2.4$ dan $\mathrm{C} 2.2$; $\mathrm{C} 2.4$ dan $\mathrm{C} 3.2$; C2.4 dan $\mathrm{C} 2.1 ; \mathrm{C} 2.3$ dan $\mathrm{C} 2.2 ; \mathrm{C} 2.3$ dan $\mathrm{C} 3.2 ; \mathrm{C} 2.3$ dan $\mathrm{C} 2.1 ; \mathrm{C} 2.2$ dan dan C3.2; serta C2.2 dan C2.1.

Hubungan antara variabel D2 dan E8 pada faktor 3, dimana keikutsertaan dalam pengelolaan (D2) tinggi apabila efek negatif hutan mangrove menjadi area wisata (E8) tinggi. Sebaliknya, keikutsertaan dalam pengelolaan (D2) rendah apabila efek negatif hutan mangrove menjadi area wisata (E8) rendah. Hal ini berlaku pada hubungan antara variabel frekuensi pemanfaatan (C3.3) dan pengetahuan tentang ekowisata (E2) pada faktor 4.

\section{b. Pengelola}

Dari pengamatan dan analisis terhadap pengelola, ternyata terdapat 5 variabel yang dapat dikategorikan dalam 2 faktor penting. Hasil analisis faktor dapat dilihat pada Tabel 2.

Tabel 2 menunjukkan korelasi antara masing-masing variabel dalam faktor 1 dan faktor 2 . Nilai dari masing-masing variabel memiliki korelasi yang tinggi, sehingga apabila salah satu variabel terganggu maka akan mempengaruhi variabel lainnya. Berbeda dengan nilai antara faktor 1 dan faktor 2, apabila salah satu faktor terganggu maka faktor lainnya tidak akan terpengaruh. Hal ini dikarenakan antara faktor 1 dengan faktor 2 memiliki nilai korelasi yang rendah. Berdasarkan

\footnotetext{
${ }^{0}$ Copyright by Saintek Perikanan (Indonesian Journal of Fisheries Science and Technology), ISSN : 1858-4748
} 
Tabel 5, dapat dilihat bahwa terdapat 2 faktor penting dalam kategori pengelola dimana faktor 1 yang memiliki nilai korelasi 0,961 sampai $(-0,632)$ dan faktor 2 yang memiliki nilai korelasi 0,976 sampai $(-0,936)$. Faktor-faktor tersebut dapat dilihat pada Gambar 2.

Tabel 2. Matriks Rotasi Komponen Kategori Pengelola

\begin{tabular}{|c|c|c|c|}
\hline \multirow{2}{*}{ Kode } & \multicolumn{2}{|c|}{ Faktor } & \multirow{2}{*}{ Keterangan } \\
\hline & 1 & 2 & \\
\hline $\mathrm{C} 4$ & .961 & -.077 & $\begin{array}{l}\text { Rekomendasi dan upaya } \\
\text { pengembangan ekowisata }\end{array}$ \\
\hline B6 & .902 & .244 & $\begin{array}{l}\text { Ancaman bagi kondisi hutan } \\
\text { mangrove }\end{array}$ \\
\hline B12 & -.632 & -.151 & $\begin{array}{l}\text { Pengaruh upaya konservasi terhadap } \\
\text { kondisi hutan mangrove }\end{array}$ \\
\hline B11 & -.096 & .976 & $\begin{array}{l}\text { Respon masyarakat terhadap } \\
\text { kelompok dalam pengelolaan }\end{array}$ \\
\hline $\mathrm{C} 1$ & -.168 & -.936 & $\begin{array}{l}\text { Kondisi hutan mangrove dilihat dari } \\
\text { kerapatan dan keragaman }\end{array}$ \\
\hline
\end{tabular}

Sumber: Hasil Penelitian, 2016

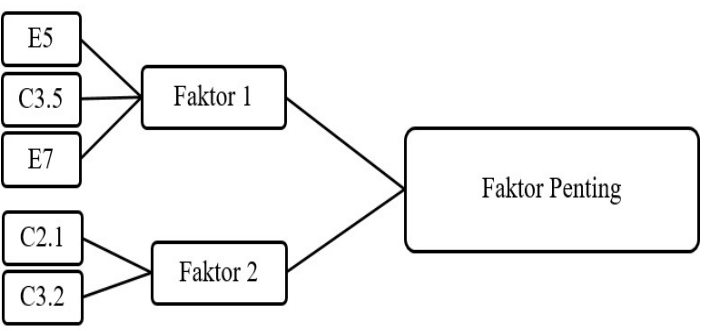

Gambar 2. Faktor Penting Pengelola

Faktor 1 dapat disebut sebagai faktor upaya pengelolaan dan pengaruhnya. Nilai yang didapat pada masing-masing variabel dalam faktor 1 bervariasi (positif dan negatif), yang artinya apabila salah satu nilai variabel naik maka nilai variabel lainnya turun. Misalnya hubungan antara variabel B6 dan B12, apabila pengaruh upaya konservasi terhadap hutan mangrove (B12) rendah maka ancaman bagi kondisi hutan mangrove (B6) akan tinggi. Sebaliknya, pengaruh upaya konservasi terhadap hutan mangrove (B12) tinggi maka ancaman bagi kondisi hutan mangrove (B6) akan rendah. Hal ini berlaku pada hubungan antara C4 (rekomendasi dan upaya pengembangan ekowisata) dan B12 (pengaruh upaya konservasi terhadap hutan mangrove).

Faktor 2 merupakan faktor respon masyarakat terhadap pengelolaan. Nilai yang didapat pada masing-masing variabel dalam faktor 1 bervariasi (positif dan negatif). Hubungan antara variabel B11 dan $\mathrm{C}$, dimana apabila kondisi hutan mangrove dilihat dari kerapatan dan keragaman (C1) tinggi, maka respon masyarakat terhadap kelompok dalam pengelolaan (B11) rendah. Sebaliknya, apabila kondisi hutan mangrove dilihat dari kerapatan dan keragaman $(\mathrm{C} 1)$ rendah, maka respon masyarakat terhadap kelompok dalam pengelolaan (B11) tinggi.

\section{c. Pelaku Perikanan}

Berdasarkan pengamatan dan analisis terhadap pelaku perikanan,ternyatadapat dikategorikan 3 faktor penting dari 12 variabel yang didapat. Hasil analisis faktor dapat dilihat pada Tabel 3.

Tabel 3. Matriks Rotasi Komponen Kategori Pelaku Perikanan

\begin{tabular}{|c|c|c|c|c|}
\hline \multirow{2}{*}{ Kode } & \multicolumn{3}{|c|}{ Faktor } & \multirow{2}{*}{ Keterangan } \\
\hline & 1 & 2 & 3 & \\
\hline $\mathrm{C} 2.1$ & ,938 & ,269 & ,205 & $\begin{array}{l}\text { Pengetahuan tentang fungsi } \\
\text { hutan mangrove }\end{array}$ \\
\hline D2 & ,938 & ,269 & ,205 & Pengetahuan tentang ekowisata \\
\hline D1 & ,938 & 269 & 205 & Pelaku pengelolaan ekowisata \\
\hline D7 &,- 938 &,- 269 &,- 205 & $\begin{array}{l}\text { Kegiatan ekonomi di area } \\
\text { wisata }\end{array}$ \\
\hline $\mathrm{C} 3.7$ & ,277 & ,935 & 220 & $\begin{array}{l}\text { Frekuensi kegiatan di kawasan } \\
\text { hutan mangrove }\end{array}$ \\
\hline C 3.1 & , 109 & 887 &, 173 & Tingkat manfaat mangrove \\
\hline C 3.3 & ,396 & 820 & ,228 & $\begin{array}{l}\text { Frekuensi memanfaatkan } \\
\text { mangrove }\end{array}$ \\
\hline D8 &,- 396 &,- 820 &,- 228 & $\begin{array}{l}\text { Efek negatif pengembangan } \\
\text { hutan mangrove menjadi area } \\
\text { wisata }\end{array}$ \\
\hline $\mathrm{C} 3.5$ &,- 061 & ,400 & 873 & $\begin{array}{l}\text { Faktor pengganggu ekosistem } \\
\text { mangrove }\end{array}$ \\
\hline $\mathrm{C} 2.2$ & ,475 &,- 145 & ,868 & $\begin{array}{l}\text { Fungsi ekologis hutan } \\
\text { mangrove }\end{array}$ \\
\hline $\mathrm{C} 2.4$ & ,333 & ,436 & ,796 & Fungsi fisik hutan mangrove \\
\hline D3 & ,237 & ,260 & ,767 & $\begin{array}{l}\text { Tanggapan tentang hutan } \\
\text { mangrove menjadi area wisata }\end{array}$ \\
\hline
\end{tabular}

Sumber: Hasil Penelitian, 2016

Tabel 3 menunjukkan korelasi antara masing-masing variabel dalam faktor 1 , faktor 2 dan faktor 3. Nilai dari masing-masing variabel memiliki korelasi yang tinggi, sehingga apabila salah satu variabel terganggu maka akan mempengaruhi variabel lainnya. Berbeda dengan nilai antara faktor 1 dengan faktor lainnya (faktor 2 dan faktor 3), apabila salah satu faktor terganggu maka faktor lainnya tidak akan terpengaruh. Hal ini dikarenakan antara faktor 1 dengan faktor lainnya (faktor 2 dan faktor 3) memiliki nilai korelasi yang rendah. Berdasarkan Tabel 6 dapat dilihat bahwa terdapat 3 faktor penting dalam kategori pelaku perikanan dimana faktor 1 yang memiliki nilai korelasi 0,938 sampai $(-0,938)$; faktor 2 yang memiliki nilai korelasi 0,935 sampai $(-0,820)$; dan faktor 3 yang memiliki nilai korelasi 0,873 sampai 0,767 . Faktorfaktor tersebut dapat dilihat pada Gambar 3.

Faktor 1 merupakan faktor pengetahuan, faktor 2 merupakan faktor frekuensi dan pemanfaatan serta faktor 3 merupakan faktor fungsi dan perusak ekosistem mangrove. Nilai yang didapat pada masing-masing variabel dalam faktor 1 bervariasi (positif dan negatif), yang artinya apabila salah satu nilai variabel naik maka nilai variabel lainnya turun. Misalnya hubungan antara variabel C2.1 dan D7, apabila pengetahuan tentang fungsi hutan mangrove (C2.1) tinggi maka kegiatan ekonomi di area wisata (B6) akan rendah. Sebaliknya, apabila pengetahuan tentang fungsi hutan mangrove (C2.1) rendah maka kegiatan ekonomi di area wisata (B6) akan tinggi. Hal ini 
berlaku pada hubungan antara D2 dan D7 serta D1 dan D7. Namun berbeda dengan hubungan antara pengetahuan tentang fungsi hutan mangrove (C2.1) dengan pengetahuan tentang ekowisata (D2) dan pelaku pengelolaan ekowisata (D1) karena nilainya positif sehingga apabila pengetahuan tentang fungsi hutan mangrove (C2.1) tinggi maka pengetahuan tentang ekowisata (D2) dan pelaku pengelolaan ekowisata (D1) tinggi. Sebaliknya, apabila pengetahuan tentang fungsi hutan mangrove $(\mathrm{C} 2.1)$ rendah maka pengetahuan tentang ekowisata (D2) dan pelaku pengelolaan ekowisata (D1) rendah.

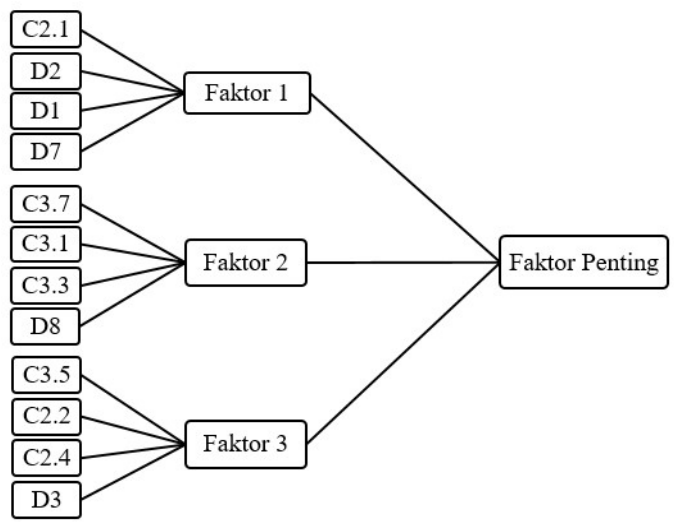

Gambar 3. Faktor Penting Pelaku Perikanan

Nilai yang didapat pada masing-masing variabel dalam faktor 2 bervariasi (positif dan negatif). Hubungan variabel frekuensi kegiatan di kawasan hutan (C3.7), tingkat manfaat mangrove (C3.1) dan frekuensi memanfaatkan mangrove (C3.3) bernilai positif, sehingga apabila salah satu nilai tinggi maka nilai lainnya akan tinggi. Sebaliknya, apabila salah satu nilai rendah maka nilai lainnya rendah. Namun akan berbeda apabila hubungan antara nilai variabel frekuensi kegiatan di kawasan hutan (C3.7) tinggi maka efek negatif pengembangan hutan mangrove menjadi area wisata (D8) rendah. Sebaliknya, apabila nilai variabel frekuensi kegiatan di kawasan hutan (C3.7) rendah maka efek negatif pengembangan hutan mangrove menjadi area wisata (D8) tinggi. Hubungan kedua variebel tersebut berlaku pula pada hubungan antara tingkat manfaat mangrove (C3.1) dengan efek negatif pengembangan hutan mangrove menjadi area wisata (D8) serta hubungan antara frekuensi memanfaatkan mangrove (C3.3) dengan efek negatif pengembangan hutan mangrove menjadi area wisata (D8).

Nilai yang didapat pada masing-masing variabel dalam faktor 3 adalah positif, yang artinya apabila salah satu nilai variabel naik maka nilai variabel lainnya naik. Sebaliknya, apabila salah satu nilai variabel turun maka nilai variabel lainnya turun.

\section{d. Pembahasan}

Faktor penting pada masyarakat terdiri dari 4 faktor yaitu (1) wisata alam, (2) fungsi dan manfaat, (3) partisipasi masyarakat dalam pengelolaan dan frekuensi pemanfaatan, dan (4) pengetahuan. Faktor wisata alam terdiri dari fungsi sosial hutan mangrove, kegiatan ekonomi apabila kawasan hutan mangrove dijadikan area wisata, jenis dan potensi untuk area wisata dan asal pengunjung atau wisatawan. Apabila jenis wisata dan potensi di kawasan hutan mangrove bagus, maka akan semakin tinggi tingkat ketertarikan pengunjung untuk datang. Hal tersebut juga akan berdampak pada kegiatan ekonomi yang ada apabila kawasan hutan mangrove dijadikan area wisata. Frekuensi pemanfaatan dan pengetahuan menjadi faktor penting dikarenakan pengetahuan tersebut dapat membawa masyarakat untuk mengetahui hal-hal lain mengenai hutan mangrove. Pengetahuan merupakan hal yang dibutuhkan dalam rangka perubahan pola pikir suatu kelompok atau masyarakat. Pengetahuan ini terkait dengan frekuensi pemanfaatan yang dilakukan oleh masyarakat. Hasil penelitian ini sama dengan hasil penelitian Pratama (2014) yang mengatakan bahwa semakin tinggi pengetahuan masyarakat maka semakin tinggi pula kesadaran masyarakat dalam berpartisipasi melestarikan hutan mangrove, sebaliknya semakin rendah pengetahuan masyarakat maka semakin rendah pula kesadaran masyarakat dalam berpartisipasi melestarikan hutan mangrove. Sependapat dengan Setyawan (2015) yang menyatakan bahwa faktor penting (kekuatan) untuk strategi pengelolaan ekowisata hutan mangrove adalah persepsi dan partisipasi masyarakat. Perhatian Pemda dan partisipasi masyarakat dalam upaya pelestarian mangrove yang belum merata di seluruh wilayah pantai di Kabupaten Brebes menjadi salah satu faktor penting (kelemahan) dalam membuat strategi pengelolaan (Suyono, 2015). Penelitian Maro (2016) menunjukkan hasil yang sama, bahwa kendala yang sangat berpengaruh dalam pengelolaan rehabilitasi hutan mangrove di kawasan Kelurahan Welai Timur dan Kelurahan Welai Barat Kabupaten Alor adalah aspirasi dan peran masyarakat dalam rehabilitasi hutan mangrove. Faktor yang merusak ekosistem mangrove (faktor manusia) akan semakin tinggi, dikarenakan tingginya kegiatan ekonomi yang dilakukan di kawasan hutan mangrove tersebut. Menurut Mulyadi et al. (2010), kerusakan hutan mangrove disebabkan oleh dua hal yaitu aktivitas manusia dan faktor alam. Aktivitas manusia yang menyebabkan kerusakan hutan mangrove adalah perambahan hutan mangrove secara besar-besaran untuk pembuatan arang, kayu bakar dan bahan bangunan, serta penguasaan lahan oleh masyarakat, pembukaan lahan untuk pertambakan ikan dan garam, pemukiman, pertanian, pertambangan dan perindustrian.

Faktor penting pengelola terdiri dari 2 faktor yakni (1) upaya pengelolaan dan (2) pengaruh serta respon masyarakat terhadap pengelolaan. Upaya pengelolaan dan rekomendasi dalam pengembangan ekowisata yang dilakukan oleh pengelola (Kelompok Pantai Lestari), ternyata memiliki pengaruh terhadap kondisi hutan mangrove itu sendiri. Ancaman yang dapat terjadi di kawasan hutan mangrove Pantai Karangsong diantaranya abrasi pantai, ROB (pasang tertinggi), alih fungsi guna lahan dan lain sebagainya. Upaya yang telah dilakukan oleh pengelola terhadap ancaman yang terjadi di kawasan hutan mangrove menurut pengelola sudah cukup baik. Namun dalam hal ini partisipasi stake holder (pemangku kepentingan) perlu dimaksimalkan, misalnya mengikutsertakan masyarakat sekitar dalam pengelolaan kawasan hutan mangrove. Noviantyet al. (2011), berpendapat bahwa pelibatan masyarakat dalam perencanaan perlu diperhatikan, karena keterlibatan masyarakat akan menciptakan rasa tanggungjawab bersama sehingga diperoleh kerja yang terbaik.Respon masyarakat terhadap kegiatan pengelolaan sudah cukup baik. Respon masyarakat terhadap pengelola tinggi dikarenakan kondisi hutan mangrove apabila dilihat dari kerapatan dan

${ }^{\circ}$ Copyright by Saintek Perikanan (Indonesian Journal of Fisheries Science and Technology), ISSN : 1858-4748 
keragamannya rendah, sebaliknya apabila kondisi hutan mangrove dilihat dari kerapatan dan keragaman tinggi (bagus) maka respon masyarakat rendah. Sependapat dengan penelitian Mulyadi et al. (2010), menyatakan bahwa faktor yang berkontribusi positif terhadap pemeliharaan dan pelestarian hutan mangrove di Kawasan Sungai Wain Balikpapan, yaitu kondisi umum hutan mangrove, peran serta dan kesadaran masyarakat, pelaksanaan kebijakan pemerintah dan dukungan Undang-undang, dukungan BLH dan perguruan tinggi.

Faktor penting pelaku perikanan terdiri dari 3 faktor yakni (1) pengetahuan, (2) frekuensi pemanfaatan dan (3) faktor perusak ekosistem mangrove. Pengetahuan para pelaku perikanan tentang fungsi hutan mangrove dan ekowisata merupakan faktor penting. Hal ini dikarenakan apabila para pelaku perikanan tidak memiliki pengetahuan yang cukup mengenai hutan mangrove, akan berdampak terhadap frekuensi pemanfaatan hutan mangrove. Apabila frekuensi pemanfaatan tinggi, maka akan berpengaruh terdapat efek negatif yang dihasilkan dari pengembangan kawasan hutan mangrove menjadi area wisata. Menurut masyarakat, salah satu efek negatif yang dihasilkan adalah semakin bertambahnya sampah, rusaknya ekosistem mangrove dan lain sebagainya. Sependapat dengan penelitian Kustantiet al. (2012), menyatakan bahwa peningkatan pengetahuan dan keterampilan dalam pengelolaan mangrove secara berkala akan berpengaruh terhadap masyarakat, sehingga mereka tahu manfaat dan fungsi hutan mangrove bagi kehidupan juga mengenal berbagai tanaman mangrove.

Faktor penting selanjutnya yaitu fungsi dan faktor perusak ekosistem mangrove. Fungsi hutan mangrove yang berpengaruh yaitu fungsi ekologis dan fungsi fisik. Di kawasan rehabilitasi magrove Pantai Karangsong, faktor yang mengganggu kawasan hutan mangrove kebanyakan adalah ulah manusia. Jadi, apabila para pelaku perikanan memahami fungsi dari hutan mangrove maka faktor yang merusak kawasan hutan mangrove dapat dihindari. Sama halnya dengan faktor penting pada masyarakat, faktor pengetahuan menjadi faktor yang paling penting pula bagi para pelaku perikanan. Hasil penelitian ini sama dengan hasil penelitian Pratama (2014) yang mengatakan bahwa semakin tinggi pengetahuan masyarakat maka semakin tinggi pula kesadaran masyarakat dalam berpartisipasi melestarikan hutan mangrove, sebaliknya semakin rendah pengetahuan masyarakat maka semakin rendah pula kesadaran masyarakat dalam berpartisipasi melestarikan hutan mangrove.

\section{KESIMPULAN}

Berdasarkan pendekatan kepada beberapa kategori masyarakat, pengelola dan pelaku perikanan, maka faktorfaktor penting yang ditemukan dari masing-masing kategori tersebut adalah sebagai berikut:

a. Faktor penting untuk kategori masyarakat terdiri dari(1) faktor wisata alam,(2) faktor fungsi dan manfaat, (3) faktor partisipasi masyarakat dalam pengelolaan serta frekuensi pemanfaatan dan (4) faktor pengetahuan.

b. Faktor penting untuk kategori pengelola terdiri dari (1) faktor upaya pengelolaan dan (2) faktor pengaruhnya serta respon masyarakat terhadap pengelolaan.

c. Faktor penting untuk kategori pelaku perikanan terdiri dari (1) faktor pengetahuan, (2) faktor frekuensi pemanfaatan serta fungsi dan (3) faktor perusak ekosistem mangrove.

\section{UCAPAN TERIMA KASIH}

Penulis mengucapkan terima kasih kepada semua pihak yang telah membantu dalam penyelesaian artikel ini, terlebih kepada Kelompok Pantai Lestari atas ijin dan bantuan selama penelitian.

\section{DAFTAR PUSTAKA}

Arikunto, S. 2006. Prosedur Penelitian Suatu Pendekatan Praktik. Rineka Cipta, Jakarta.

Gay, L.R dan P.L. Diehl. 1992. Research Methods for Business and Management. MacMillan Publishing Company, New York.

Hair, J.F., R.E. Anderson, R.L. Tatham and W.C. Black. 1998. Multivariate Data Analysis (fifth edition). Prentice Hall International, INC, New Jersey.

Kustanti, A., B. Nugroho., D. Durusman dan C. Kusmana. 2012. Integrated Management of Mangroves Ecosystem in Lampung Mangrove Center (LMC) East Lampung Regency, Indonesia. Journal of Coastal Development., 15(2):209-216.

Maro, J.F. 2016. Algoritma Karbon Biomassa Mangrove Berdasarkan Citra Satelit Alos_Avnir_2 di Kelurahan Welai Timur dan Kelurahan Welai Barat Kabupaten Alor. [Tesis]. Program Pascasarjana, Universitas Diponegoro, Semarang.

Mulyadi, Edi., O. Hendriyanto dan N. Fitriani. 2010. Konservasi Hutan Mangrove sebagai Ekowisata. Jurnal Ilmiah Teknik Lingkungan., 1: 51-57.

Novianty, R., S. Sukajaya dan D. J. Prihadi. 2011. Identifikasi Kerusakan dan Upaya Rehabilitasi Ekosistem Mangrove di Pantai Utara Kabupaten Subang. Jurnal Akuatika., 2(2):1-9.

Peraturan Desa Nomor 02 Tahun 2009 tentang Pengelolaan Daerah Perlindungan Mangrove Desa Karangsong.

Pratama, R.R. 2014. Pengaruh Tingkat Pendidikan, Pendapatan dan Pengetahuan terhadap Partisipasi Nelayan dalam Pelestarian Mangrove di Pantai Timur Surabaya. Universitas Negeri Surabaya. 57-68.

Prayudha, E.D., B. Sulardiono dan B. Hendrarto. 2014. Strategi Kelompok Pantai Lestari dalam Pengembangan Kegiatan Rehabilitasi Mangrove di Desa Karangsong Kabupaten

\footnotetext{
${ }^{0}$ Copyright by Saintek Perikanan (Indonesian Journal of Fisheries Science and Technology), ISSN : 1858-4748
} 
Indramayu. Diponegoro Journal of Maquares., 3(3): 8087.

Purnamasari, R., D. Suprapto dan F. Purwanti. 2015. Pengembangan Ekowisata Mangrove Desa Karangsong, Kabupaten Indramayu. Diponegoro Journal of Maquares., 4(4): 146-154.

Santoso, S. 2004. Buku Latihan SPSS Statistik Multivariat. PT. Elex Media Komputindo, Jakarta.

Savitri, L.A. dan M. Khazali. 1999. Pemberdayaan Masyarakat dalam Pengelolaan Wilayah Pesisir, Pengalaman Pelaksanaan Pengembangan Tambak Ramah Lingkungan dan Rehabilitasi Mangrove di Indramayu. Wetlands International Indonesia Programme. Bogor.
Setyawan, E. 2015. Strategi Pengelolaan Ekowisata Hutan Mangrove Berdasarkan Kesesuaian dan Daya Dukung Kawasan di Desa Pasarbanggi Kabupaten Rembang Provinsi Jawa Tengah. [Tesis]. Program Pascasarjana, Universitas Diponegoro, Semarang.

Sugiyono. 2008. Metode Penelitian Kuantitatif Kualitatif dan Research dan Development. Bandung Alfabeta, Bandung.

2012. Metode Penelitian Bisnis. Bandung Alfabeta, Bandung.

Suyono. 2015. Strategi Penanganan Kerusakan Mangrove di Wilayah Pantai Kabupaten Brebes Propinsi Jawa Tengah. [Disertasi]. Program Pascasarjana, Universitas Diponegoro, Semarang. 